\title{
BUSINESS MODEL CANVAS AND STRATEGIES TO DEVELOP BIODIESEL INDUSTRY OF PT. XYZ IN ORDER TO IMPLEMENT CPO SUPPORTING FUND POLICY
}

\author{
Aman Mustika*), Rina Oktaviani**), and Sukardi***) \\ *) School of Business, Bogor Agricultural University \\ SB IPB Building, Pajajaran Road, Bogor, Indonesia 16151 \\ **) Department of Economic, Faculty of Economics and Management, Bogor Agricultural University \\ Jl. Agatis, IPB Dramaga Campus Bogor 16680 \\ ${ }^{* * *}$ Department of Agroindustrial Technology, Faculty of Agricultural Technology, Bogor Agricultural Institute \\ Building Fateta Floor 2, IPB Darmaga Campus, Bogor 16680
}

\begin{abstract}
Biodiesel is considered as one of the alternative eco-friendly fuels. Besides, the government also issued policy related to biodiesel that is CPO Supporting Fund (CSF) Policy. The aim of the research is to identify Business model canvas (BMC) biodiesel industry in PT XYZ and to know the strategies to develop business from biodiesel industry in line with the CPO supporting fund policy. The analysis tool used in this research is BMC, SWOT and Quantitative Strategic Planning Matrix (QSPM). The research results in identifying BMC of PT XYZ is customer segment that the company serves in the form of domestic as well international customers. The value the company offers is biodiesel quality that is in accordance with SNI standard and the distribution is at the company's cost; the relationship built with the customers is by communities and co-creation; the marketing network through stock exchanges and commodity exchanges; the revenue obtained from selling biodiesel and the price difference between biodiesel and solar from BPDPKS; the company's resources are human resource, raw material resource, and financial resource; the main activities carried out by the company is CPO process to become biodiesel and sale; the company's partners are GAPKI, BPDPKS and APROBI; the cost structure is operational cost, workers' salary, and CPO levy fund. Furthermore, the strategy to develop biodiesel industry in line with the rapid increase of competitiveness is to increase the biodiesel production capacity and communication improvement and CRM to improve customers' service.
\end{abstract}

Keywords: biodiesel, CPO supporting fund (CSF), levy fund, vegetable oil (BBN), business model canvas (BMC)

\begin{abstract}
Abstrak: Biodiesel merupakan salah satu bahan bakar alternatif yang ramah lingkungan. Selain itu Pemerintah juga telah mengeluarkan kebijakan terkait dengan biodiesel, yaitu Kebijakan CPO Supporting Fund (CSF). Tujuan dalam penelitian ini untuk mengidentifikasi Business Model Canvas (BMC) industri biodiesel di PT XYZ dan mengetahui strategi pengembangan bisnis dari industri biodiesel seiring dengan implementasi kebijakan CPO Supporting Fund. Alat analisis yang digunakan dalam penelitian ini adalah BMC, SWOT dan Quantitative Strategic Planning Matrix (QSPM). Hasil penelitian dalam mengidentifikasi BMC PT. XYZ adalah segmen pelanggan yang dilayani perusahaan berupa pelanggan domestic dan internasional; nilai yang ditawarkan perusahaan adalah kualitas biodiesel sesuai standar SNI dan biaya distribusi ditanggung perusahaan; hubungan yang dibangun dengan pelanggan dengan cara komunitas dan co-creation; jaringan pemasaran melalui pasar modal dan bursa komoditi; penerimaan pendapatan yang diperoleh penjualan biodiesel dan bantuan selisih harga biodiesel dengan solar dari BPDPKS; sumber daya yang dimiliki oleh perusahaan adalah sumber daya manusia, sumber daya bahan baku dan sumber daya finansial; aktivitas utama dilakukan perusahaan adalah pengolahan CPO menjadi biodiesel dan penjualan; mitra perusahaan adalah GAPKI, BPDPKS dan APROBI; struktur biaya adalah biaya operasional, biaya gaji pegawai dan biaya pungutan CPO. Selain itu diperoleh strategi untuk mengembangkan industri biodiesel seiring dengan meningkatnya persaingan yang semakin pesat adalah untuk meningkatkan kapasitas produksi biodiesel dan peningkatan komunikasi dan CRM untuk meningkatkan layanan pelanggan.
\end{abstract}

Kata kunci: biodiesel, CPO supporting fund (CSF), dana pungutan, bahan bakar nabati (BBN), bisnis model canvas (BMC)

\footnotetext{
${ }^{1}$ Corresponding author:

Email:aman_mustika@yahoo.com
} 


\section{INTRODUCTION}

Biodiesel is one the alternative eco-friendly fuels because it does not emit polutant that is dangerous for health. The use of biodiesel as motor fuel can reduce emission compared to diesel oil. Biodiesel is made of vegetable oil coming from renewable sources. Some raw materials for making biodiesel, among others, palm oil, soybean, sunflowers, fenced jojoba, and canes (Rahayu, 2007). Biodiesel materials that have a good prospect and big chance to be processed to become biodiesel are palm oil. Compared to other vegetable oil producing trees, palm oil is the most efficient oil producing raw material (Masykur, 2013). Biodiesel that is processed into palm oil has several superiorities, namely safer from fire when it is kept and distributed, it is easily mixed with diesel, and it has high cetane and its availability is plenty in Indonesia (the Ministry of Republic of Indonesia, 2013). The amount of cetane contained in biodiesel is quite high, namely $>50$ or almost the same as cetane contained in diesel (Bustaman, 2009). Besides, from the automotive viewpoint, biodiesel has more advantages, namely protecting the machine, increasing burning efficiency (Tety et al. 2012).

In 2015 the area of palm oil was 10.9 million hectares producing 29.3 million tons CPO (Directorate General of Plantation, 2015). CPO production is expected to increase and in 2020 it is predicted to reach 40 million tons. The chance to develop palm-oil-based biodiesel is quite promising, especially to substitute diesel. The needs for biofuel in the form of biodiesel keep increasing, especially in the transportation sector, as can be seen in Figure 1. Besides transportation sector, biodiesel is also widely used the sector of diesel-powered electricity industry (PLTD) (Sembiring, 2015).

Biodiesel is one the products from palm-oil downstream industries belonging to half-ready industry in the form of chemical oleo (Pahan, 2008). Based on the palm oil industry (Ministry of Industry, Republic of Indonesia, 2011) it shows that biodiesel is also one of the third derivative products of palm oil that has been produced in domestic palm oil industries. The needs for biodiesel keep increasing in accordance with the suggestion to use vegetable fuel that is more eco-friendly. This can be seen from the increase of biodiesel consumption for 218,875 kilolitres in 2017, and in 2025 it is expected to increase up to 6,187,449 kilolitres (Maulana and Aziz, 2012).

Benefits and superiority of biodiesel make it one of the important aspects of interesting CPO derivative product. Besides, the government has also issued related policy to biodiesel that is CPO Supporting Fund (CSF) Policy. CPO Supporting Fund (CSF) is the government policy related to the levy fund charged to the palm oil producers for CPO export effective in April 2015. The CSF policy is taken as one of the government steps to overcome world CPO prices that keep decreasing which is relatively lower, especially in September 2015 , falling to US $\$ 450$ per ton.

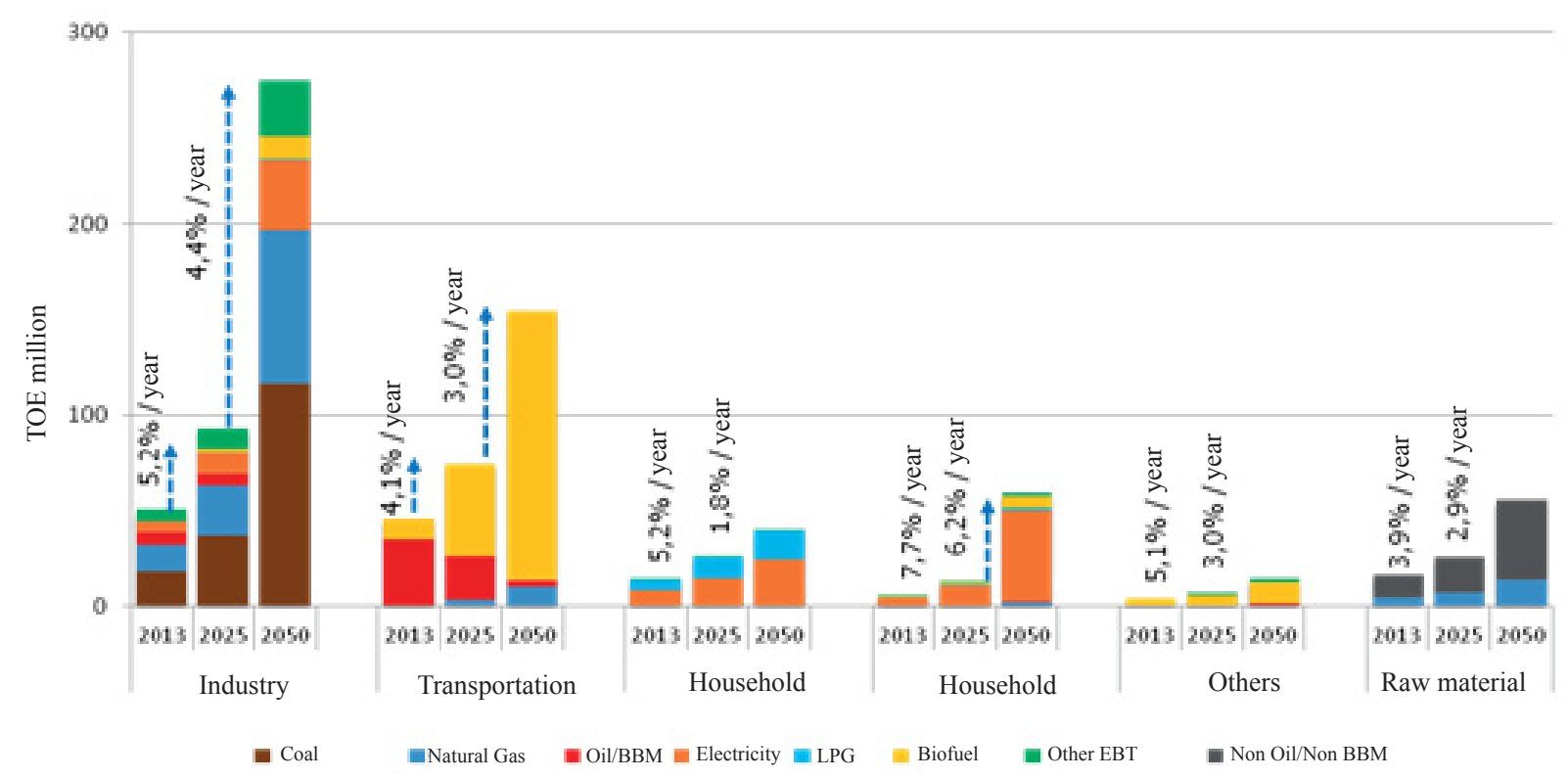

Figure 1. Projection of final energy needs (The Ministry of Energy and Mineral Resources, 2014) 
The foundation for implementing CSF is Law No 392014 concerning Plantation to collect fund from plantation businessmen. The levy fund is used, among others, for research and development to support the sustainability of the plantation. CPO Fund policy is aimed in the short term reducing CPO supply in the international market and in the long term at supporting in-country biodiesel development (vegetable fuel). The CPO levy fund reaches US $\$ 50$ per ton for crude palm oil, while for oleic export reaches US $\$ 30$ per ton (Murtiningrum, 2016). The levy fund is effective as a substitute for exit customs duty, when the crude palm oil price is below US $\$ 750$ per ton. If the price of crude palm oil is above $\$ 750$, the CPO Fund will be deducted from exit customs duty.

The CSF levy fund that has been collected from palm oil businessmen will be managed by the Management Team for Palm Oil Fund based on the Government Decree No. $61 / 2015$ the CSF levy fund is used for the cost and CPO subsidy that will become biodiesel as vegetable fuel. With the existence of CSF, the CPO program is expected to become the source for vegetable fuel in accordance with the regulation issued by the Ministry of Energy and Mineral Resources No 292015 concerning development of biofuel of biodiesel type for mixed biodiesel. The CSF policy issued by the government makes biodiesel industry coming from palm oil has a great business chance. Business opportunity for biodiesel industry increases biodiesel industries, one of which is PT XYZ.

The condition of palm oil that is going down has a big impact on palm oil industries, including biodiesel industries whose raw material is crude palm oil. The CPO price that decreased in 2015 affected the efficiency of operational activities maximally, including biodiesel industry. However, the presence of CSF policy issued by the government makes the CPO price increase. In the last five years the CPO price had fallen, and in September 2015 it reached the lowest point, namely US $\$ 480$ per ton. In April 2016 it started to recover, that is US \$ 640 per ton.

The implementation of CSF policy that can increase CPO price and increase biodiesel chance to become vegetable fuel has made PT XYZ start to run their biodiesel industry maximally. However, to run it operation maximally, PT XYZ must have a business model and strategy. To develop biodiesel industry from palm oil, strategic planning must be made and carried out in order to face environmental condition and very tight business competition. Since the company CSF policy that focused on producing biodiesel to become vegetable fuel was implemented, there have been 11 companies. Some big companies that are involved are PT Wilmar, PT Musim Mas and PT Damex (the Ministry of Energy and Mineral Resources, 2015). Based on those problems, the aims of the research are as follows: identifying business model canvas in biodiesel industry that comes from crude palm oil in PT XYZ using BMC approach and finding out the strategies and development of biodiesel industry from CPO in line with the implementation of CPO Fund policy.

The research was carried out in Jakarta and Pekanbaru. Furthermore, this research was limited to analyzing the biodiesel industry BMC originating from $\mathrm{CPO}$ at PT $\mathrm{XYZ}$. The analysis carried out was only integrated into the policy - the government policy related to biodiesel industry and its use as a vegetable fuel.

The research on CPO covers industry and government policies, such as the one conducted by Wijaya (2015), that is carrying out research concerning biodiesel policy formulation using regulatory impact analysis and dynamic methods. The research results show that to reach biodiesel mandatory, it is necessary to have integrated policy package in the form of mandatory of using biodiesel, giving exported CPO disincentive, giving CPO incentive as the raw material for biodiesel, and increasing biodiesel capacity. Wiharjanto (2013) also carried out research to analyze the strategy to develop palm oil downstream industry at PT SMART Tbk. The research results show that the strategy of business integration carried out by a company focusing on development of resources and technology is appropriate and effective.

Masykur (2013) carried out research of developing palm oil industry as an alternative energy source that can reduce global warming. He carried out research in Riau as the biggest palm oil producer in Indonesia. The research results show that the prospect for developing palm oil industry is very fast, in which there is an increasing number of palm oil production in line with the increase of Riau people's needs specifically, Indonesia's, in general, and Uni-European countries' as the biggest consumers of $\mathrm{CPO}$ in the world. With the advantages owned by palm oil industry from upstream to downstream, this research was carried out to find out the company business strategies in facing CPO supporting Fund policies. 
Various researches have also been carried out about business model canvas (BMC) in formulating strategies. This model business is usually used by companies that are at the initial level of entering market, at development level or at the level when the companies need improvement. Like Boedianto and Harjanti (2015); Hudori (2014) also carried out similar research related to business development strategies using the same analytical methods as BMC and SWOT. The result of the research by Boedianto and Harjanti (2015) shows that the most important element is key partnership, because the relationship between companies and its business partners is very good. On the other hand the result of Hudori's research says that to make use of the strong fundamental industry, it is necessary to carry out expansion both in upstream business and downstream business. Therefore, this research is important to conduct so that companies will know the strategies and positions of the companies to develop their business using a BMC approach.

\section{METHODS}

Types of data used in this research covered primary and secondary data with the time range between January and December 2015. Data were obtained from field observation, the Ministry of Agriculture, the Ministry of Energy and Mineral Resources, Plantation Agency, bulletins, websites and some institutions related to palm oil. The primary data of this research will be collected through in-depth interview and another research instrument, that is questionnaire carried out to respondents. Respondents are selected using purposive sampling technique. The number of respondents is considered based on each competency in palm oil downstream industry especially biodiesel, whether it is internal or external (Sugiyono, 2009). Purposive sampling is sample determination using a special technique to understand an internal as well as external condition of an event.

In this research business model canvas is chosen as a method in making business development in PT XYZ. The research framework can be seen in Figure 2. The analysis instruments used in the research are BMC, SWOT, and QSPM. BMC is aimed at finding out the existing business model implementation and development of business strategies (Boedianto and Harjanti, 2015). Besides, BMC also analyzes business model from the customer segment, value proposition, distribution channel, customers' relationship to increase product sale and service (Wiska, 2016). SWOT is aimed at identifying strategic factors of the company including strength, weakness, opportunity, and threat during the present condition (Hudori, 2014). The use of BMC and SWOT in analyzing business model will make it possible to get stronger SWOT evaluation. Combination of both analyzing means will make it complete. BMC will be used to evaluate integration, the whole business model, whereas SWOT is used to see all components in detail so that business model development will be more effective. The results of the analysis using BMC and SWOT produce some alternative business development strategies that will be selected using QSPM. The use of QSPM as a tool to develop business is very appropriate to carry out analysis and evaluation on each determined strategy (Harisudin, 2013).

The following is the stages of research carried out to analyze business model canvas in order to implement CSF policy:

1. Stage One is carried out to identify Business model canvas (BMC)

BMC identification stage is the initial stage to collect data through in depth interview carried out to resource persons coming from the internal company. The results of in depth interview are put into nine BMC elements. The nine BMC elements are customer segment, value proposition, customer relationship, channels, revenue stream, key activities, key resources, key partnership and cost structure.

2. Stage Two is making SWOT analysis from each BMC element.

This stage includes collecting data and classifying them and also pre-analysis. In this stage data to be analyzed are distinguished into two parts, namely internal and external (Rangkuti, 2013).

a. Internal data are obtained from inside the company such as report on human resources, report on finance, report on company's operational activities, report on marketing activities, and so on.

b. External data are obtained from outside the company including market analysis, competitor analysis, community analysis, supplier analysis, government analysis, and certain stakeholder analysis. 
3. Stage Three is making IFE and EFE matrix and making development strategies from BMC elements that have been determined. This stage is the stage to review and analyze factors of the business model canvas elements to be developed. Besides, there is also a strategic formulation to be carried out.

4. Stage Four is setting up QSPM (Quantitave Strategic Planning Matrix). In this stage prioritized strategies to be carried out by PT XYZ are chosen in order to develop biodiesel industry.

\section{RESULTS}

\section{Description of Business Model using Business model canvas}

Based on the results of in depth interview activities with resource persons as the company management, it is known that there are some variables that become elements of business model canvas of PT XYZ, which is presented in Table 1, business model canvas of PT $\mathrm{XYZ}$ at this moment. Every BMC element in biodiesel industry of PT XYZ has an important role, in which each element will influence the biodiesel industry operation at PT XYZ.

\section{Customer Segment}

Based on the results of in depth interview types of customer segment that exist in PT XYZ are included into "pasar ceruk". Pasar ceruk is a type of segmentation that has business model with the target to serve pasar ceruk that is specific and specified
(Nurmanisa et al. 2016). Customer relationship is made specific for pasar ceruk's needs. Based on the resulting product specification, customer segmentation can be divided into two: namely domestic (in-country and international). Product produced by PT XYZ especially from downstream industry sector which is biodiesel depends on the customers' needs that are PT Pertamina, PT. Petro Energy and PT. Petronas Niaga Indonesia. Biodiesel that is produced is tailored to biodiesel quality standard that has been determined. Biodiesel standard for domestic market is: SNI 7182; 2015, for US market is ASTM D-6751 and for European market is EN 14214.

\section{Value Proposition}

Based on the results of in depth interview and field observation, PT. XYZ has value propositions in biodiesel industry that is biodiesel as vegetable fuel, eco-friendly biodiesel, biodiesel quality that is marketed is in accordance with the standard (SNI Biodiesel) and the cost for distribution is the responsibility of PT XYZ.

\section{Channel}

Channels carried out by PT. XYZ Company are giving information, distributing and selling directly to consumers. To distribute the product especially CPO and biodiesel, PT. XYZ has owned shipping industry that can help distribution activities. Furthermore, information delivery for marketing and selling products is carried out through capital market/ stock exchange and commodity exchanges.

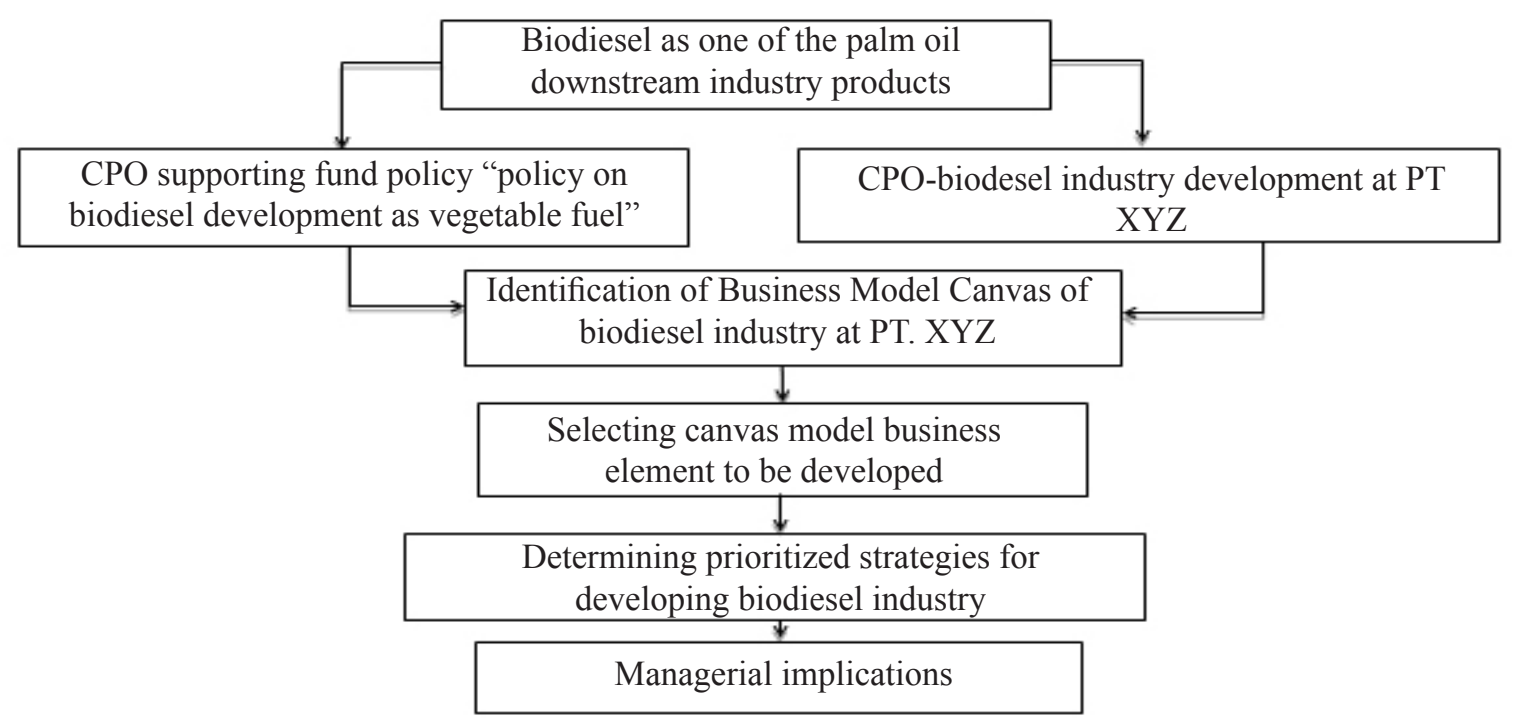

Figure 1. Research framework 
Table 1. The present canvas model business of PT. XYZ

\begin{tabular}{|c|c|c|c|c|}
\hline Key partnership & Key activities & Value proposition & Customer relationship & Customer Segment \\
\hline \multirow[t]{3}{*}{$\begin{array}{l}\text { 1. GAPKI } \\
\text { 2. BPDPKS } \\
\text { 3. } \text { APROBI }\end{array}$} & 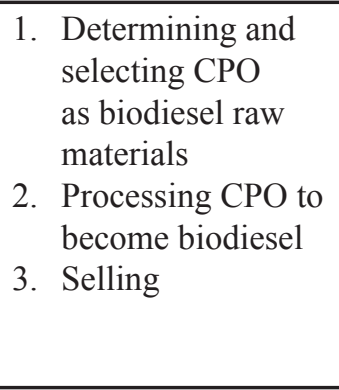 & \multirow{3}{*}{ 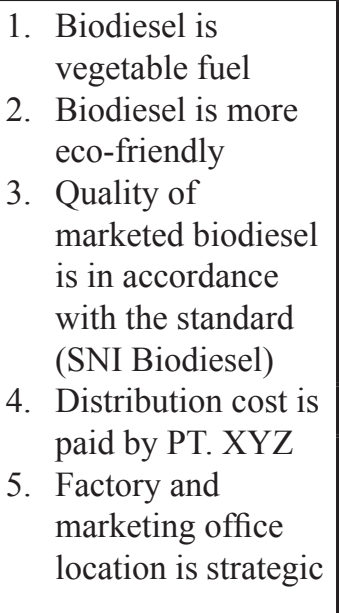 } & \begin{tabular}{|ll} 
1. & Communities \\
& (GAPKI and \\
& APROBI) \\
2. & Co-Creation \\
a. & PT. Pertamina \\
b. & PT. Petro Energy \\
c. & PT. Petro Niaga \\
& Indonesia
\end{tabular} & \multirow[t]{3}{*}{$\begin{array}{l}\text { 1. Domestic } \\
\text { 2. International }\end{array}$} \\
\hline & Key resources & & Channels & \\
\hline & $\begin{array}{l}\text { 1. Human resources } \\
\text { 2. Raw material } \\
\text { resources } \\
\text { 3. Financial resources }\end{array}$ & & $\begin{array}{l}\text { 1. Capital market/Stock } \\
\text { exchange } \\
\text { 2. Commodity } \\
\text { exchanges }\end{array}$ & \\
\hline \multicolumn{3}{|l|}{ Cost structure } & \multicolumn{2}{|l|}{ Revenue Stream } \\
\hline \multicolumn{3}{|c|}{$\begin{array}{l}\text { 1. Factory operational cost } \\
\text { 2. Workers' salary } \\
\text { 3. Raw material cost for making biodiesel } \\
\text { 4. CPO levy fund according to CSF policy }\end{array}$} & \multicolumn{2}{|c|}{$\begin{array}{l}\text { 1. Selling biodiesel (main product) } \\
\text { 2. Selling glycerol (by-product) } \\
\text { 3. Profit from selling share } \\
\text { 4. Difference between biodiesel price and diesel } \\
\text { price from BPDPKS }\end{array}$} \\
\hline
\end{tabular}

\section{Customer Relationship}

Based on in depth interview that has been carried out with communities and co-creation, co-creation is a relationship between customer and company to create value together with customers (Setijawibawa, 2015). Community is carried out by building information access among customers in a community (GAPKI and APROBI) to find out the customers' needs (PT. Pertamina, PT. Petro Energy, and PT. Petro Niaga Indonesia).

\section{Revenue Stream}

The revenue that is obtained by PT. XYZ comes through product sale-products that are produced and sold directly to customers and stock sale. Besides that, with the implementation of CSF policy PT XYZ gets considerable revenue from the price difference of biodiesel and diesel. This revenue is obtained from BPDPKS as a levy fund management agency based on CSF policy.

\section{Key Activity}

Based on the results of in depth interview and field observation, PT. XYZ has specific key activities in biodiesel industry. This is determining and selecting qualified CPO for biodiesel raw materials. Activities to determine and select $\mathrm{CPO}$ are an important initial process in biodiesel industry. The CPO quality will affect the quality of biodiesel produced. A good CPO quality for biodiesel has FFA content (Free Fatty Acid) approximately 2\% (Rachmaniah et al. 2009). Furthermore, key activities in PT. XYZ biodiesel industry is CPO process to become biodiesel and to be sold to customers.

\section{Key Resources}

PT. XYZ is superior in raw material resources, because the main raw material is CPO that is obtained from CPO factories that is still in one company group. PT $\mathrm{XYZ}$ also has a big palm oil plantation as the producer of palm oil fresh bunches. Based on the operational data, PT XYZ has more than 200,000 Ha palm oil plantations, 14 units of palm oil factories and I unit of biodiesel factory in Dumai - Pekanbaru.

\section{Key Partnership}

Some major partners of PT. XYZ in carrying out its model business, especially the one that is related to biodiesel, are as follows: GAPKI (Indonesian Palm Oil Businessmen Association), BPDPKS (Palm Oil Plantation Fund Management Agency), and APROBI (Indonesian Biodiesel Producer Association). The three major partners of PT. XYZ hold important roles 
in carrying out model business, especially in managing and developing palm oil business that is eco-friendly.

\section{Cost Structure}

The cost structure in PT. XYZ in running its company includes factory operational cost, workers' salary, raw material cost such as $\mathrm{CPO}$ and chemical materials (methanol), maintenance cost and marketing cost, including the levy fund according to CSF policy that must be submitted to BPDPKS.

\section{SWOT Element analysis of Canvas Model Business}

Based on the SWOT analysis carried out to each element of business model canvas of PT. XYZ at present, it is known that there are two potential elements to be developed, namely customer relationship and cost structure. Both elements have the highest weighted scores in each SWOT element. The weighted scores of SWOT analysis are presented in Table 2.

Customer Relationship has the highest strength and opportunity compared to other BMC elements. The weighted strength score of Customer Relationship element is 2.65 and its opportunity is 2.80 . The strength of PT. XYZ from the customer relationship element is networking with oil companies that are corporate with the government (PT. Pertamina, PT. Petro and PT. Petronas Niaga Indonesia) and joining in the community that support biodiesel industry business (GAPKI and APROBI). Both strengths give opportunity to PT. XYZ in biodiesel industry, namely increasing collaborated service, such as email, personalized publishing, e-communities, discussion forum and other means that are designed to facilitate interaction between customers and the company.

Cost structure element in PT XYZ is one that needs to be developed because it has substantial weakness and threat in palm oil downstream industry especially biodiesel market. Based on the SWOT analysis that has been carried out, the weakness has a weighted score 1.94 and the threat 2.29. The weakness of PT. XYZ in cost structure element is inappropriate efficiency in using the cost and very little maintenance cost. As for the threat, the following must be dealt with:

a. The fall of oil price increases the difference between diesel price and biodiesel price

b. Biodiesel price cannot compete with diesel price c. The thirty-day payment system for the difference between biodiesel price and diesel price from palm oil BPDP will interfere with cash flow of downstream industry that produces biodiesel.

\section{Development of BMC elements and prioritized strategies}

BMC elements that have been determined to be developed according to SWOT analysis are Customer Relationship and Cost Structure. Both elements need to be developed because they have substantial potential and weakness in biodiesel industry from the developed $\mathrm{CPO}$ in line with the implementation of CPO Supporting Fund policy (Table 3).

\section{Customer Relationship element}

Based on the factor's internal and external data analysis and QSPM, it is shown that there are two important alternative strategies for customer relationship element, namely: 1) Increasing CRM (Customer Relationship Management) with TAS 6.93;2) Developing product with TAS 6.80 result.

The analysis result using QSPM shows that the strategy that has the highest total attractiveness score (TAS) is Increasing CRM (Customer Relationship Management).

According to customer relationship element, PT. XYZ needs to develop strategies, namely: Increasing CRM (Customer Relationship Management) focusing on formation that is followed by customers for the long term that can give added-value to the customers and also to the company. CRM is an appropriate strategy to make relationship and to create customer loyalty (Mokodongan, 2010). Furthermore, CRM is also a business philosophy that describes a strategy to put clients as the center of process, activities, and culture (Dyantina et al. 2012). Biodiesel Customer is so specific that it needs a CRM strategy to understand what $\mathrm{s} /$ he needs, especially the one related to biodiesel. The quality of biodiesel produced must be in accordance with the biodiesel specification from the customers, especially the biodiesel sentane content. Besides that, PT XYZ also must be able to supply biodiesel tailored to the demand agreed together. One of the examples is PT. XYZ and PT. Pertamina makes an agreement to buy and sell biodiesel every six months. 
Table 2. SWOT analysis of each BMC element

\begin{tabular}{cccccccccc}
\hline \multirow{2}{*}{ SWOT elements } & \multicolumn{10}{c}{ BMC elements } \\
\cline { 2 - 10 } & CS & VP & CH & CR & RS & KA & KR & KP & C $\$$ \\
\hline S & 2.54 & 1.74 & 1.72 & 2.65 & 1.71 & 1.04 & 1.10 & 1.58 & 1.38 \\
W & 1.02 & 1.73 & 1.79 & 0.96 & 1.52 & 0.94 & 1.74 & 1.67 & 1.94 \\
O & 1.98 & 1.72 & 2.24 & 2.80 & 2.05 & 0.98 & 1.48 & 1.16 & 1.76 \\
T & 2.12 & 1.27 & 1.18 & 1.46 & 1.70 & 0.89 & 1.31 & 2.64 & 2.29 \\
\hline
\end{tabular}

Table 3. Calculation of TAS value from customer relationship element

\begin{tabular}{|c|c|c|c|c|c|}
\hline \multirow[t]{2}{*}{ Critical Success Factors } & \multirow[t]{2}{*}{ Weight } & \multicolumn{2}{|c|}{$\begin{array}{c}\text { Strategy I } \\
\text { "Improving CRM } \\
\text { (Customer Relation } \\
\text { Management)" }\end{array}$} & \multicolumn{2}{|c|}{$\begin{array}{c}\text { Strategy II } \\
\text { "Product } \\
\text { Development" }\end{array}$} \\
\hline & & (AS) & TAS & (AS) & TAS \\
\hline \multicolumn{6}{|l|}{ Strength } \\
\hline Motivating customers' loyalty & 0.16 & 5.00 & 0.80 & 3.00 & 0.48 \\
\hline Improving operational efficiency, esp. marketing & 0.15 & 3.00 & 0.44 & 4.00 & 0.59 \\
\hline Improving time to market & 0.13 & 4.00 & 0.51 & 4.00 & 0.51 \\
\hline $\begin{array}{l}\text { Enable consumers to determine biodiesel specification acc. to } \\
\text { their needs }\end{array}$ & 0.14 & 3.00 & 0.42 & 4.00 & 0.56 \\
\hline \multicolumn{6}{|l|}{ Weaknesses } \\
\hline Having the potential to change organization & 0.11 & 4.00 & 0.45 & 3.00 & 0.34 \\
\hline Relationship with non-PSO customers is not maximum & 0.12 & 4.00 & 0.48 & 3.00 & 0.36 \\
\hline $\begin{array}{l}\text { Biodiesel product still focus on domestic biodiesel product } \\
\text { specification }\end{array}$ & 0.10 & 3.00 & 0.30 & 4.00 & 0.40 \\
\hline Customer data management is not strong & 0.09 & 2.00 & 0.19 & 4.00 & 0.37 \\
\hline \multicolumn{6}{|l|}{ Opportunity } \\
\hline $\begin{array}{l}\text { getting new potential customers in order to reach interna- } \\
\text { tional market }\end{array}$ & 0.19 & 4.00 & 0.77 & 3.00 & 0.57 \\
\hline $\begin{array}{l}\text { Knowing the customers' needs related to biodiesel specifica- } \\
\text { tion acc to the needs }\end{array}$ & 0.18 & 3.00 & 0.55 & 4.00 & 0.73 \\
\hline Creating competitive advantage & 0.14 & 4.00 & 0.56 & 3.00 & 0.42 \\
\hline Increasing sales turnover & 0.13 & 3.00 & 0.39 & 4.00 & 0.52 \\
\hline \multicolumn{6}{|l|}{ Threat } \\
\hline Increased CPO biodiesel industries & 0.12 & 3.00 & 0.37 & 3.00 & 0.37 \\
\hline $\begin{array}{l}\text { Potential biodiesel industry opportunity makes market share } \\
\text { higher, esp with businessmen dominating market share }\end{array}$ & 0.12 & 4.00 & 0.49 & 2.00 & 0.24 \\
\hline $\begin{array}{l}\text { The difference between biodiesel and diesel prices will lower } \\
\text { customers' interest in using biodiesel as vegetable fuel }\end{array}$ & 0.11 & 2.00 & 0.23 & 3.00 & 0.34 \\
\hline Total & & 51.00 & 6.93 & 51.00 & 6.80 \\
\hline
\end{tabular}

\section{Cost Structure element}

Based on the factor's internal and external data analysis and QSPM, it is shown that there are two strategic alternatives that are needed by cost structure element, namely: 1) Increasing the biodiesel production capacity with TAS 7.65 result. 2) Reducing the market index value (HIP) of biodiesel with TAS 6.04 result.
The analysis result using QSPM shows that the strategy that has the highest total attractiveness score (TAS) is increasing the biodiesel production capacity. One of the prioritized strategies that need to be developed is increasing the biodiesel production capacity. The strategy is appropriate to use because it can reduce the production cost. If the capacity of biodiesel production can be increased, it can reduce its production cost. Cost reduction can happen in accordance with the economic 
scale principle, namely reduced production cost per unit in one company that happens simultaneously with the increase of the total production. The strategy of increasing biodiesel production capacity has two advantages, namely:

\section{a. Low production cost}

Reduced cost production happens because the more biodiesel produced the less the production cost. Hence, competitive production cost (HPP) can be reached. Biodiesel production cost can be competitive if it is not so much different from the diesel price and lower than the biodiesel selling price determined by the Ministry of Energy and Mineral Resources.

\section{b. Market share of biodiesel increases}

The market share of biodiesel that is determined by PT. Pertamina as the major consumer of biodiesel is based on the biodiesel production capacity that is owned by the company and its capacity to supply biodiesel demand determined by PT. Pertamina.

\section{Managerial Implications}

CSF policy implementation that has been effective since June 2015 has given positive impacts especially for biodiesel industry originating from CPO. For PT. $\mathrm{XYZ}$ the implementation of CSF policy gives it two advantages, namely increasing CPO sale and increasing revenue. According to the financial data of PT. XYZ, it is known that the balance between levy fund in selling $\mathrm{CPO}$ and its by-product with the difference between biodiesel price and diesel is highly positive. The revenue obtained from selling biodiesel is Rp320,000,000,000 and the levy fund submitted is Rp120,000,000,000 (Data from PT. XYZ financial department, 2016). PT XYZ profit from selling biodiesel comes from domestic market with customers that have considerable demand, namely PT. Pertamina. There are also 2 other customers that also give profit, namely PT. Petro Energy and PT. Petronas Niaga Indonesia. According to the information obtained from in depth interview and data from the company's financial department, it is known that working contract related to biodiesel selling has increased, namely:

Before the development strategies are applied:
PT. Pertamina
: 4,000 kiloliter / 2 weeks
PT. Petro Energy

PT. Petronas Niaga : 1,500 kiloliter / 2 weeks Indonesia

After the development strategies are applied:

\begin{tabular}{|c|c|}
\hline PT. Pertamina & 5,495 kiloliter / 2 weeks \\
\hline PT. Petro Energy & 2,000 kiloliter / 2 weeks \\
\hline $\begin{array}{l}\text { PT. Petronas Niaga } \\
\text { Indonesia }\end{array}$ & 1,800 kiloliter / 2 \\
\hline
\end{tabular}

The profit obtained is because of the CSF implementation that can increase the interest of PT. $\mathrm{XYZ}$ interest in biodiesel industry and some other biodiesel industry businessmen to compete in biodiesel market. Therefore, based on the analysis carried out, PT. $\mathrm{XYZ}$ has applied a strategy, that is increasing biodiesel production capacity. The aim of increasing biodiesel production capacity is to get low production cost so that the biodiesel production cost can be competitive and can increase PT XYZ market share in biodiesel market. This implemented strategy by PT. XYZ is an appropriate strategy because one of the components to determine the size of biodiesel market share is the size of biodiesel production capacity. The higher the biodiesel production capacity is, the higher the capacity to supply biodiesel to markets and thus increasing the market share. Besides that, it can increase an added value for the customers and for PT. XYZ, namely increasing CRM.

\section{CONCLUSIONS AND RECOMMENDATIONS}

\section{Conclusions}

Based on the analysis of BMC that is implemented in PT. XYZ biodiesel, there are two elements that need to be improved to face biodiesel market competition, namely customer relationship and cost structure. Both elements need to be developed because they have substantial potential and weakness in biodiesel industry from the developed CPO in line with the implementation of CPO Supporting Fund policy.

The result of the internal and external analysis on cost structure element shows that the present weakness cannot catch up with the company internal strength so that it is necessary to use a strategy to make the company financial condition be strong especially to obtain the biodiesel production cost that can compete with the market biodiesel price from the Ministry of Energy 
and Mineral Resources. Therefore, an appropriate prioritized strategy to develop biodiesel business in the market is to increase the cooperative contract with customers and to increase biodiesel production capacity so that the production cost of biodiesel can compete with the price of pure diesel.

\section{Recommendations}

Based on the above conclusion, it is recommended that the government should give support especially in determining regulations related to the implementation of CSF policy so that all the palm oil industry businessmen in general and specially biodiesel industry can get the results. Furthermore, the company needs to increase biodiesel production capacity so that the biodiesel production cost can compete in the biodiesel market that is fluctuating and also compete with the pure diesel price.

For further research on biodiesel industry development and the implementation of CPO Supporting Fund policy, it is better if the research object focuses on the advantages and disadvantages of the implementation of CPO Supporting Fund policy, both for the government and for the company.

\section{REFERENCES}

Bustaman S. 2009. Strategi pengembangan industri biodiesel berbasis kelapa di Maluku. Jurnal Litbang Pertanian 28(2): 46-53.

Boedianto LP, Harjanti D. 2015. Strategi pengembangan bisnis pada depot selaras dengan pendekatan businmess canvas model. Jurnal Agora 3(2): 292-301.

Boedianto LP, Harjanti D. 2015. Strategi pengembangan bisnis pada depot selaras dengan pendekatan businmess canvas model. Jurnal Agora 3(2):292-301.

Dyantina O, Afrina M, Ibrohim A. 2012. Penerapan Customer Relationship Management (CRM) berbasis web (studi kasus pada sistem informasi penukaran di toko Yen-Yen). Jurnal Sistem Informasi 4(2): 516-529.

Harisudin M. 2013. Pemetaaan dan strategi pengembangan agroindustri tempe di Kabupaten Bojonegoro Jawa Timur. Jurnal Teknologi Industri Pertanian 23(2): 120-128.

Hudori M. 2014. Review bisnis model dan daya saing industri agribisnis. Malikussaleh Industrial Engineering Journal 4(1): 56-61.

[ESDM] Kementerian Energi Sumber Daya Mineral Republik Indonesia. 2015. Outlook Energi Indonesia. Jakarta: ESDM.

[Kemendag] Kementerian Perdagangan Republik Indonesia. 2013. Analisis Peningkatan Penggunaan Biodiesel Sebagai Upaya Mengatasi Defisit Neraca Perdagangan Migas. Jakarta: Kemendag.

Masykur. 2013. Pengembangan industri kelapa sawit sebagai penghasil energi bahan bakar alternatif dan mengurangi pemanasan global. Jurnal Reformasi 3(2): 96-107.

Maulana A, Aziz M. 2012. Kinerja dan prospek pengembangan bahan bakar nabati di Indonesia. Jurnal Agro Ekonomi 30(2): 147-158.

Murtiningrum FA. 2016. Perkembangan biodiesel di Indonesia tinjauan atas kondisi saat ini, teknologi produksi \& analisis prespektif. Jurnal PASTI 9(1): 35-45.

Nurmanisa A, Wilopo, Sanawiri B. 2016. Analisis customer segment, channel dan customer relationship dalam pembentukan value proposition di Starbucks Coffe. Jurnal Administrasi Bisnis 34(1): 10-18.

Pahan I. 2008. Panduan Lengkap Kelapa Sawit Manajemen Agribisnis dari Hulu Hingga Hilir. Jakarta: Penebar Swadaya.

Rachmaniah O, Baidawi A, Latif I. 2009. Produksi biodiesel berkemurnian tinggi dari Crude Palm Oil (CPO) dengan tertrahidrofuron-fast singlephase process. Jurnal Reaktor 12(3): 166-174.

Rahayu M. 2007. Teknologi Proses Produksi Biodiesel. Jakarta: Badan Penelitian dan Pengembangan Teknologi.

Rangkuti F. 2013. Teknik Membedah Kasus Bisnis: Analisis SWOT, Cara Perhitungan Bobot, Rating dan OCAI. Jakarta: PT Gramedia Pustaka Utama.

Sembiring MT. 2015. Model biaya produksi biodiesel berbasis minyak sawit. Jurnal Litbang Industri 5(1): 23-36. https://doi.org/10.24960/jli. v5i1.663.23-36.

Setijawibawa M. 2015. Evaluasi model bisnis pada perusahaan $\mathrm{x}$ menggunakan business model canvas. Jurnal AGORA 3(1): 305-313.

Sugiyono. 2009. Metode Penelitian Kuantitatif dan Kualitatif. Bandung: Remaja Rosdakarya.

Tety E, Hutabrat A, Putra F. 2012. Prospek komoditas minyak kelapa sawit(CPO) dalam pengembangan 
biodiesel sebagai alternatif bahan bakar di Indonesia. Jurnal Pebkis 4(3): 152-162.

Wiharjanto. 2013. Analisis strategi pengembangan industri hilir kelapa sawit pada PT SMART Tbk [tesis]. Yogyakarta: Universitas Gadjah Mada.

Wiska F, Syarief R, Baga LM. 2016. Mengambangkan sekolah peternakan rakyat menggunakan pendekatan bisnis model canvar case study:
Kota Bojonegoro. Indonesia Journal of Business and Entrepreneruship 2(2) : 69-81. https://doi. org/10.17358/IJBE.2.2.69.

Wijaya H. 2015. Perumusan kebijakan biodiesel kelapa sawit dengan menggunakan metode regulatory impact analysis dan model sistem dinamis [tesis]. Bogor: Institut Pertanian Bogor. 